\title{
MANAGEMENT OF SEED MYCOFLORA OF MESTA (Hibiscus sabdariffa) BY SEED WASHING, GARLIC EXTRACT AND KNOWIN
}

\author{
M. S. Islam ${ }^{1 *}$, M. S. I. Uzzal ${ }^{1}$, K. Mallick ${ }^{1}$ and M. S. Monji1 ${ }^{2}$ \\ Department of Plant Pathology, Bangladesh Agricultural University \\ Mymensingh-2202 Bangladesh
}

\begin{abstract}
Mesta (Hibiscus sabdariffa) is one of the important fibre crops having worldwide acceptance. The crop was found to susceptible to a number of seed and seedling disease causal pathogens; most of them were seed-borne in nature. Germination of seeds and seed-borne fungi were recorded using standard blotter method which varied significantly among different treatments ranged from $84 \%$ to $97.33 \%$. The highest $(97.33 \%)$ germination was found in case seed washed with water and then treated with garlic extract $(1: 1)$ and washing of seeds with water followed by treating with Knowin 50 WP. Nine different fungi were detected in samples of mesta seeds in using standard blotter method. The fungi were Macrophomina phaseolina, Botryodiplodia theobromae, Colletotrichum corchori, Curvularia lunata, Fusarium spp., Aspergillus favus, A. niger, Penicillium spp. and Alternaria spp. The finding of the study revealed that seed washing with water followed by seed treatment with garlic extract $(1: 1)$ or Knowin 50 WP $(0.2 \%)$ resulted significant reduction of seed-borne fungal population and enhancing seeding vigor.
\end{abstract}

Key Words: Mesta, Hibiscus sabdariffa, Seed mycoflora, Seed washing, Garlic

\section{INTRODUCTION}

Mesta (Hibiscus sabdariffa) produces bast fibre and is used as a substitute for jute. It is also attracting the attention of food and beverage manufacturers and pharmaceutical concerns who feel it may have exploitable possibilities as a natural food product and as a colorant to replace some synthetic dyes (Cook et al., 2000). Some people of Bangladesh use young fruits and leaves of mesta as vegetable. Worldwide, it is known as Roselle and is popular in the western world because of its eco-friendly nature. Its versatile fibre has unique properties to the best raw material viz. cordage crop to produce twine, rope, gunny bags, sackcloth, specialty papers, tea bags, grass mats, fibre glass substitute, blended with plastic, or blended with cotton for fabrics.

Diseases have been reported as a limiting factor to the production of mesta worldwide. Mesta is susceptible to a number of seed and seedling disease pathogens, most of them are seed-borne in nature. Dempsey (1975) reported that Rhizoctonia solani, Pythium spp. and

\footnotetext{
${ }^{1}$ MS Student and 2Associate Professor, Department of Plant Pathology, Bangladesh Agricultural University, Mymensingh-2202, Bangladesh

*Corresponding author
} 
Fusarium spp. were primary causal agents of seedling diseases of fibre crops, including mesta. Boulanger et al. (1984) found that F. oxysporum causes infection to stem and pod of the young plants of $H$. sabdariffa. Seed borne diseases reduce yield and market value of seeds. The pathogens can damage the crop and shrivel seeds within the pods or kill the pod stalk before seed formation. Although so much human control efforts and the use of fungicides is being devoted to the preservation of seeds, over $40 \%$ of harvested seeds can be lost through diseases (Tsai and $\mathrm{Ou}, 2002$ ).

Seed treatment, generally with a combination of selective fungicides, is a standard practice for control of the seedling disease complex (Minton and Garber 1983). White et al. (1971) reported that kenaf emergence is generally greater for chemically treated versus non-treated seeds. Cook et al. (1992) found that seed treatment combination of metalaxyl, carboxin, and captan consistently resulted in greater stands than those achieved with non-treated seed. Seed treatment with chemical is costly as well as is not friendly to environment. So, beside seed treatment, physical seed cleaning is important practice for reducing disease after sowing. Hasan (2000) reported that physical seed sorting of rice seeds resulted $8.33 \%$ germination increase over non-sorting seeds. Asad-ud-doullah (2002) published that seed cleaning, washing and seed treatment reduce disease incidence of rice seedlings. No systematic work has been done on the seed-borne diseases of this crop for assessing the seed-borne infection and seed-borne diseases of mesta in Bangladesh. Therefore, the study was undertaken with mesta seeds with the following objectives:

i. To know the seed health status as well as seed-borne fungi association in farmers stored mesta seeds

ii. To compare the efficacy of the different seed treatments in reducing the incidence of seed-borne fungi of mesta seeds

\section{MATERIALS AND METHODS}

Farmer's stored seeds of Mesta cultivar HS-24 (H. sabdariffa) were collected from five farmers of sadar upazilla of Barisal district. The seeds were then kept in brown paper bags and stored in the refrigerator at $4^{\circ} \mathrm{C}$ in Seed Pathology Center (BAU) until use. The experiment was conducted at Seed Pathology Center (SPC), Plant Disease Clinic and M.S. Laboratory, Department of Plant pathology, Bangladesh Agricultural University (BAU), Mymensingh. The experiment was conducted during the period from January 2012 to May, 2013.

Total six treatments were applied for the experiment which were $\mathrm{T}_{0}=$ Control, $\mathrm{T}_{1}=$ Water wash, $\mathrm{T}_{2}=$ Garlic extract $(1: 1), \mathrm{T}_{3}=$ Water wash + garlic extract $(1: 1), \mathrm{T}_{0}=$ Knowin $50 \mathrm{WP}$ (Carbendazim) @ 0.2\% and $\mathrm{T}_{5}=$ Water wash + Knowin 50 WP @ $0.2 \%$. Garlic extract was prepare by using the method described by Hossain et al. (1997). For water wash, $5 \mathrm{~g}$ of seeds were taken in petridish and washed with running tap water properly. After wash, seeds were placed in open air for drying $(4-5 \mathrm{~h})$. Seed treatment with garlic extracts was done by dipping seeds in previously prepared garlic extracts $(1: 1)$ for 20 minutes. Chemical fungicide, Knowin $50 \mathrm{WP}$ was tested as a seed treating chemical. Five grams of seeds and $.01 \mathrm{~g}$ of Knowin $50 \mathrm{WP}$ were taken in a $250 \mathrm{ml}$ of Erlenmeyer flask and were shaken for 
$10 \mathrm{~min}$ for proper coating. The treated and untreated seeds were tested for seed-borne fungi following the standard blotter method (ISTA, 1999). Four replications were conducted for each sample. After incubations, the germination of seeds and yielded fungi were counted.

The incubated seeds were observed individually under stereomicroscope and the associated pathogens were detected by observing their growth characters on the incubated seeds on blotter paper following the keys outlined by Khan and Islam (1975). For proper identification of fungi, temporary slides were prepared from the fungal colony, observed under a compound microscope, and identified.

For examine seedling vigor, treated mesta seeds were sown in trays containing sands. After 10 days of sowing, shoot length and root length were measured and seedling vigor was calculated as vigor index following the formula given by Baki and Anderson (1972). The collected all data were analyzed and mean differences among the treatments were compared by Duncan's Multiple Range Test (DMRT). A statistical computer package MSTAT-C was used for analyzing the data.

\section{RESULTS}

Germination of seeds and seed-borne fungi were recorded using standard blotter method. Germination significantly varied in different treatments ranged from $84 \%$ to $97.33 \%$. The lowest $(84.00 \%)$ germination of seeds was found in untreated seeds $\left(\mathrm{T}_{0}\right)$ and the highest $(97.33 \%)$ germination was found on Water wash + garlic extract $\left(\mathrm{T}_{3}\right)$ and Water wash + Knowin 50 WP @ 0.2\% ( $T_{5}$ ) (Table 1). Nine different fungi were detected in all samples of mesta seeds under control condition $\left(\mathrm{T}_{0}\right)$ using standard blotter method. These fungi are Macrophomina phaseolina, Botryodiplodia theobromae, Colletotrichum corchori, Curvularia lunata, Fusarium spp., Aspergillus favus, A. niger, Penicillium spp and Alternaria spp.

Different seed treatments namely, physical seed wash, garlic extract and chemical fungicide and their combination with seed wash varied significantly. The complete eradication of $C$. corchori, B. theobromae, C. lunata, and Alternaria spp. was observed in seed samples treated with garlic extract $\left(\mathrm{T}_{2}\right)$ and water wash + Knowin $50 \mathrm{WP}\left(\mathrm{T}_{3}\right)$ at the rate of $0.2 \%$ of seed weight. Reduced percentage of these fungi were also observed with the treatments T1 (Water wash) and $\mathrm{T}_{4}$ (Knowin $50 \mathrm{WP}$ ) in compare to control $\left(\mathrm{T}_{0}\right)$. Application of Water wash+garlic extract $\left(\mathrm{T}_{3}\right)$ completely eradicated the association of C. corchori, M. phaseolina, $B$. theobromae, A. niger and Alternaria spp. (Table 1). Total seed-borne infection was lowest in Water wash + Knowin 50 WP @ $0.2 \%$ while the second best performance was recorded by the treatment with Water wash + garlic extract. Treatment with Garlic extract and Knowin 50 WP @ 0.2\% showed good performance yielding reduced fungal population. On the other hand, only water wash was found to be effective in reducing total fungal population.

Seedling vigor of mesta seeds were tested against different treatments. Mesta seed samples showed highest percentage of germination (83.00\%) in $\mathrm{T}_{5}$ (Water wash + Knowin $50 \mathrm{WP}$ ), whereas lowest percentage of seed germination $(68.00 \%)$ in $\mathrm{T}_{0}$ (Control) (Fig. 1). Higher shoot length $\left(16.32 \mathrm{~cm}\right.$ ) observed in $\mathrm{T}_{5}$ (Water wash + Knowin $\left.50 \mathrm{WP}\right)$ and whereas lowest 
shoot length $(13.20 \mathrm{~cm})$ was observed in $\mathrm{T}_{0}$ (Control) (Table 2). Higher root length $(13.02 \mathrm{~cm})$ was observed in $\mathrm{T}_{4}$ (Knowin $50 \mathrm{WP}$ ) whereas lowest root length was observed in $\mathrm{T} 0$ (Control). In vigor index, higher vigor index was found in $T_{5}$ (Water wash + Knowin 50 WP) and lowest vigor index was in $\mathrm{T}_{0}$ (Control) (Table 2).

Table 1. Effect of different treatments on germination and seed-borne fungi of mesta

\begin{tabular}{lc|c|c|c|c|c|c|c|c|c}
\hline $\begin{array}{c}\text { Treatm } \\
\text { ents }\end{array}$ & $\begin{array}{c}\text { Germina } \\
\text { tion (\%) }\end{array}$ & $\begin{array}{c}\text { Colletotri } \\
\text { chumcorc } \\
\text { hori }\end{array}$ & $\begin{array}{c}\text { Macropho } \\
\text { minapphas } \\
\text { eolina }\end{array}$ & $\begin{array}{c}\text { Botryodi } \\
\text { plodiathe } \\
\text { obromae }\end{array}$ & $\begin{array}{c}\text { Fusari } \\
\text { um } \\
s p p\end{array}$ & $\begin{array}{c}\text { Curvul } \\
\text { aria } \\
\text { lunata }\end{array}$ & $\begin{array}{c}\text { Aspergi } \\
\text { llus } \\
\text { flavus }\end{array}$ & $\begin{array}{c}\text { Aspergill } \\
\text { us niger }\end{array}$ & $\begin{array}{c}\text { Penicilli } \\
\text { um spp }\end{array}$ & $\begin{array}{c}\text { Alterna } \\
\text { ria spp }\end{array}$ \\
\hline $\mathrm{T}_{0}$ & $84.00^{\mathrm{e}}$ & $28.00^{\mathrm{a}}$ & $12.00^{\mathrm{a}}$ & $6.00^{\mathrm{a}}$ & $20.00^{\mathrm{d}}$ & $16.00^{\mathrm{a}}$ & $4.00^{\mathrm{d}}$ & $16.00^{\mathrm{a}}$ & $4.00^{\mathrm{b}}$ & $10.00^{\mathrm{a}}$ \\
$\mathrm{T}_{1}$ & $89.33^{\mathrm{de}}$ & $10.00^{\mathrm{b}}$ & $4.00^{\mathrm{b}}$ & $4.00^{\mathrm{b}}$ & $56.00^{\mathrm{a}}$ & $8.00^{\mathrm{b}}$ & $8.00^{\mathrm{c}}$ & $16.00^{\mathrm{a}}$ & $8.00^{\mathrm{a}}$ & $6.00^{\mathrm{b}}$ \\
$\mathrm{T}_{2}$ & $89.33^{\mathrm{cd}}$ & $0.00^{\mathrm{d}}$ & $4.00^{\mathrm{b}}$ & $0.00^{\mathrm{d}}$ & $48.00^{\mathrm{b}}$ & $0.00^{\mathrm{d}}$ & $12.00^{\mathrm{b}}$ & $0.00^{\mathrm{d}}$ & $0.00^{\mathrm{c}}$ & $4.00^{\mathrm{c}}$ \\
$\mathrm{T}_{3}$ & $92.00^{\mathrm{bc}}$ & $0.00^{\mathrm{d}}$ & $0.00^{\mathrm{c}}$ & $0.00^{\mathrm{d}}$ & $24.00^{\mathrm{c}}$ & $6.00^{\mathrm{c}}$ & $8.00^{\mathrm{c}}$ & $0.00^{\mathrm{d}}$ & $4.00^{\mathrm{b}}$ & $0.00^{\mathrm{d}}$ \\
$\mathrm{T}_{4}$ & $92.00^{\mathrm{ab}}$ & $4.00^{\mathrm{c}}$ & $4.00^{\mathrm{b}}$ & $2.00^{\mathrm{c}}$ & $24.00^{\mathrm{c}}$ & $0.00^{\mathrm{d}}$ & $16.00^{\mathrm{a}}$ & $12.00^{\mathrm{b}}$ & $0.00^{\mathrm{c}}$ & $0.00^{\mathrm{d}}$ \\
$\mathrm{T}_{5}$ & $97.33^{\mathrm{a}}$ & $0.00^{\mathrm{d}}$ & $0.00^{\mathrm{c}}$ & $0.00^{\mathrm{d}}$ & $16.00^{\mathrm{e}}$ & $0.00^{\mathrm{d}}$ & $0.00^{\mathrm{e}}$ & $8.00^{\mathrm{c}}$ & $0.00^{\mathrm{c}}$ & $0.00^{\mathrm{d}}$ \\
$\mathrm{LSD}_{0.05}$ & 1.779 & 1.03 & 0.623 & 0.428 & 1.92 & 0.894 & 0.389 & 0.840 & 0.210 & 0.623 \\
Level of & $* *$ & $* *$ & $* *$ & $* *$ & $* *$ & $* *$ & $* *$ & $* *$ & $* *$ & $* *$ \\
\multicolumn{2}{l}{ significance } & & & & & & & & & \\
\hline
\end{tabular}

** = Significance at 5\% level. Data were subjected to Duncan's Multiple Range Test (DMRT) using a statistical computer package (MS tatec). Each value represents the mean and std deviation of three replications. In a column, figures with same letter or without letter do not differ significantly whereas figures with dissimilar letter differ significantly (as per DMRT)

Treatments: $\mathrm{T}_{0}=$ Control, $\mathrm{T}_{1}=$ Water wash, $\mathrm{T}_{2}=$ Garlic extract $(1: 1), \mathrm{T}_{3}=$ Water wash + Garlic extract $(1: 1), \mathrm{T}_{4}=$ Knowin $50 \mathrm{WP}, \mathrm{T}_{5}=$ Water wash + Knowin 50WP

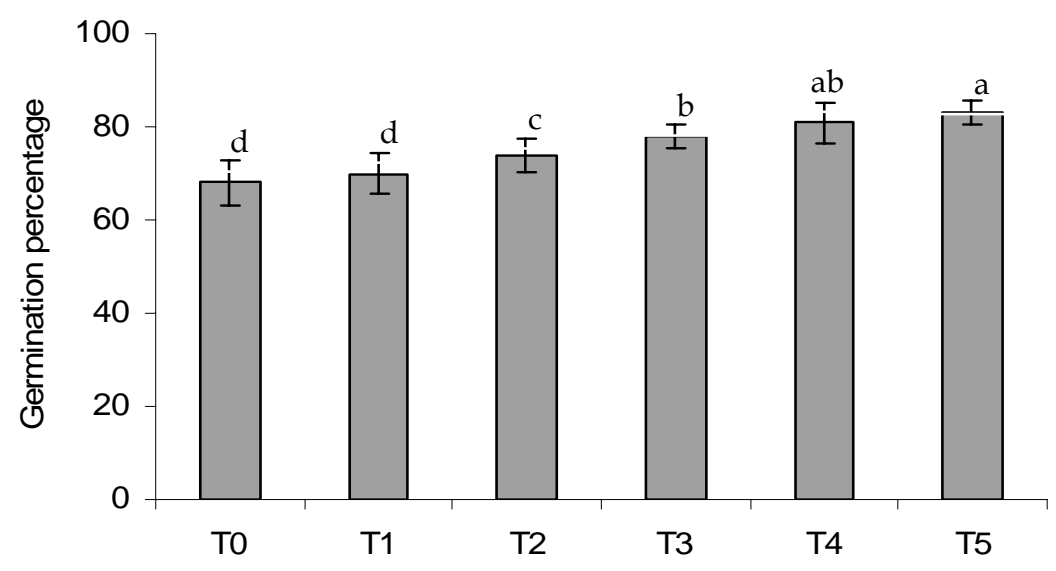

Fig. 1. Effect of different treatments on seed germination (tray sand methods). Data were subjected to Duncan's Multiple Range Test (DMRT) using a statistical computer package (MS tatec). Each value represents the mean and std deviation of three replications. Columns with same letters do not differ significantly whereas dissimilar letters differ significantly (as per DMRT). $\mathrm{T}_{0}=$ Control (non-treated), $\mathrm{T}_{1}=$ Water wash, $\mathrm{T}_{2}=$ Garlic extract, $\mathrm{T}_{3}=$ Water wash + Garlic extract, $\mathrm{T}_{4}$ $=$ Knowin $50 \mathrm{WP}$ and $\mathrm{T}_{5}=$ Water wash + Knowin 50WP 
Table 2. Effect of different treatments on mean shoot length, mean root length and vigor index of mesta seedlings

\begin{tabular}{l|c|c|c|c}
\hline \multirow{2}{*}{ Treatments } & \multicolumn{4}{|c}{ Mesta } \\
\cline { 2 - 5 } & Shoot length $(\mathrm{cm})$ & Root length $(\mathrm{cm})$ & Total length $(\mathrm{cm})$ & Vigor index \\
\hline $\mathrm{T}_{0}$ & $13.20^{\mathrm{c}}$ & $11.32^{\mathrm{b}}$ & $24.52^{\mathrm{b}}$ & $1667.36^{\mathrm{e}}$ \\
$\mathrm{T}_{1}$ & $13.98^{\mathrm{bc}}$ & $9.780^{\mathrm{c}}$ & $23.76^{\mathrm{b}}$ & $1663.20^{\mathrm{e}}$ \\
$\mathrm{T}_{2}$ & $15.34^{\mathrm{ab}}$ & $12.10^{\mathrm{ab}}$ & $27.44^{\mathrm{a}}$ & $2030.56^{\mathrm{d}}$ \\
$\mathrm{T}_{3}$ & $16.56^{\mathrm{a}}$ & $11.54^{\mathrm{b}}$ & $28.10^{\mathrm{a}}$ & $2191.80^{\mathrm{c}}$ \\
$\mathrm{T}_{4}$ & $15.38^{\mathrm{ab}}$ & $13.02^{\mathrm{a}}$ & $28.50^{\mathrm{a}}$ & $2300.40^{\mathrm{b}}$ \\
$\mathrm{T}_{5}$ & $16.72^{\mathrm{a}}$ & $12.02^{\mathrm{ab}}$ & $28.74^{\mathrm{a}}$ & $2385.42^{\mathrm{a}}$ \\
\hline $\mathrm{LSD}_{0.05}$ & 1.38 & 0.95 & 1.50 & 17.56 \\
\hline
\end{tabular}

** = Significance at 5\% level. Data were subjected to Duncan's Multiple Range Test (DMRT) using a statistical computer package (MStatec). Each value represents the mean and std deviation of three replications. Columns with same letters do not differ significantly whereas dissimilar letters differ significantly (as per DMRT). $\mathrm{T}_{0}=$ Control (non-treated), $\mathrm{T}_{1}=$ Water wash, $\mathrm{T}_{2}=$ Garlic extract, $\mathrm{T}_{3}=$ Water wash + Garlic extract, $\mathrm{T}_{4}=$ Knowin $50 \mathrm{WP}$ and $\mathrm{T}_{5}=$ Water wash + Knowin 50WP.

Treatments: $\mathrm{T}_{0}=$ Control, $\mathrm{T}_{1}=$ Water wash, $\mathrm{T}_{2}=$ Garlic extract $(1: 1), \mathrm{T}_{3}=$ Water wash + Garlic extract $(1: 1) \mathrm{T}_{4}=$ Knowin $50 \mathrm{WP}, \mathrm{T}_{5}=$ Water wash + Knowin 50WP

\section{DISCUSSION}

Seed-borne fungi is one of the major factor of low yield of mesta fiber and quality fruits. In this present work, the seed-borne fungi associated with the mesta seeds were investigated as well as their control measures were studied. Detected nine different seed-borne fungal pathogens were associated with mesta seeds (Table 1). Limited research works are published on mesta ( $H$. sabdariffa) seed quality and health. Diseases have been reported as a limiting factor to the production of mesta worldwide. The cultivated plants are susceptible to the various pathogens such as Phytophthora parasitica, Phoma sabdariffae, Rhizoctonia solani (Gomez-Leyva et al., 2008) and F. oxysporum (Amusa et al., 2005; Agbenin and Ogunlana, 2006). Nwaukwu and Ataga (2012) reported the associated fungi with H. sabdariffa seeds, viz. A. niger, A. flavus, F. oxysporum, P. chrysogenum and P. roqueforti using both blotter and agar plate methods. Singh et al. (2013) studied seed mycoflora in mesta and reported the association of different genera of fungi viz., Alternaria, Aspergillus, Curvularia, Drechslera, Fusarium, Macrophomina, Mucor, Rhizoctonia, Rhizopus, and Streptomyces on seeds of mesta which were collected from different localities of India. These results indicate that there is a variation among different seed sources with regard to seed mycoflora appearing on the plated seeds.

It is expected to be a natural phenomenon that the percent of seed germination should be increased in case of treated seeds than that of untreated seeds. Similarly, many workers found the same phenomenon when they treated the different crop seeds with different fungicides (Wahid et al., 1995 and Singh et al., 2013). Different treatments were used for controlling seed-borne fungi of mesta in this experiment. Mesta seeds cleaned with water 
(Water wash) and treating these washed seeds with botanicals (Garlic extract) or chemical (Knowin $50 \mathrm{WP}$, a fungicide of Carbendazim group) showed high germination and high vigor index comparing with the single use of these treatments (Table 1 and Fig. 1). Till now, some researchers used single treatment for controlling seed borne fungi. Ahmed and Sultana (1984) stated that jute seeds treated with garlic paste increased rate of germination and decreased rate of post emergence seedling mortality. Kabir et al. (2007) published that farmer's stored wheat seeds washed with water or brine solution increase seed germination and suppressed the incidence of Bipolaris sorokiniana. Hasan (2000) reported that rice seeds become free from Bipolaris oryzae when washed with brine solution. Panna et al. (2009) also reported reduced fungal association in seeds washed with brine solution.

These results, in conjunction with the study, provide conclusion that nine different fungi were associated in collected farmer's stored mesta seeds. This is the first study on detection of seed-borne mycoflora of mesta seeds in Bangladesh. Fungi associated mesta seeds reduced seed germination and vigor. Seed treatment with garlic extract or chemical was effective technique for reducing seed-borne mycoflora of mesta seeds, but it would be effective better when the seeds were cleaned with water (Water wash) before seed treatment with botanical or chemical fungicides.

\section{REFERENCES}

Agbenin, O. N. and Ogunlana, M. O. 2006. Occurence of Fusarium wilt and nematodes on red calyx roselle (Hibiscus sabdariffa L.) in northern Nigeria. J. Plant Prot. Res., 46(2): 117-122.

Ahmed N. and Sultana K. 1984. Fungitoxic effect of garlic on treatment of jute seed. Bangladesh J. Bot., 13(2): 130-136.

Amusa, N. A., Adegbite, A. A. and Oladapo, M. O. 2005. Vascular Wilt of Roselle (Hibiscus sabdariffa L. var. sabdariffa) in the humid forest Region of South-western Nigeria. J. Plant. Path., 4(2): 122-125.

Asad-ud-doullah, M., Anam, M. K., Nazrul Islam, M., Rahman, M., Fakir, G. A. and Hossain. I. 2002. Effect of seed cleaning, washing and seed treatment on seedling disease incidence and yield of rice. Pak. J. Biol. Sci., 5(7): 767-769.

Baki, A. A. and Anderson, J. D. 1972. Physiological \& biological deterioration of seeds. In seed Biology, Vol. 11. Academic Press, New York. pp. 283-315.

Boulanger, J., Follin, J. C. and Bourely, J. 1984. Les hibiscus textiles en Afrique tropicale, 1ère partie: conditions particulières de production du kenaf et de la roselle. Cot. Fib. Trop $5^{\text {th }}$ ed.

Cook, C. G., Hickman, M. V., Webber, C. L., Sij, J. W. and Scott, A. W. 1992. Fungicide treatment effects on kenaf seed germination and stand establishment. Ind. Crop Prod., 1: 41-45.

Cook, J. A., Vanderjagt, D. J., Pastuszyn, A., Mounkalia G., Glew, R. S., Millson, M. and Glew, R. H. 2000. Nutrient and chemical composition of 13 wild plant foods of Nigeria. J. Food Comp Anal., 13: 83-92.

Dempsey, J. 1975. Kenaf. In: Fiber Crops, pp. 203-304. The University Presses of Florida, Gainesville. Rose Printing Co., Tallahassee. 
Gomez-Leyva, J. F., Acosta, L. A. M., Muraira, I. G. L., Espino, H. S., Ramirez-Cervantes, F. and Andrade-Gonzalez, I. 2008. Multiple shoot regeneration of roselle (Hibiscus sabdariffa L.) from a shoot apex system. Intern. J. Bot., 4(3): 326-330

Hasan, M. M. 2000. Effect of seed cleaning and washing on germination disease incidence and yield of rice BR 11 (mukta). M. Sc. Thesis, Department of Plant Pathology, BAU, Mymensingh, Bangladesh.

Hossain, I., Mahamud, H. and Ashrafuzzaman, H. 1997. Effects of plant extracts on fungi (Bipolaris sorokiniana and Rhizoctonia solani) and okra mosaic disease. Ecoprint., 4(1): 35-42.

ISTA (International Seed Testing Association). 1999. International Rules for Seed Testing, International Seed Testing Association, Seed Sci. \& Technol., Zurich, Switzerland. pp. 13-15.

Kabir, M. H., Aminuzzaman, F. M., Islam, M. R. and Chowdhury, M. S. M. 2007. Effect of physical and chemical seed treatments on leaf spot (Bipolaris sorokiniana) and yield of wheat. World J. Agric. Sci., 3(3): 306-315.

Khan, A. Z. M. and Islam, N. A. S. 1975. Colletotrichum lindeinuthianum of Dolichos lablab from Bangladesh. Bangladesh J. Bot., 4(1-2): 121-123.

Minton, E. B., and Garber, R. H. 1983. Controlling the seedling disease complex of cotton. Plant Disease, 67: 115-118.

Nwaukwu, I. A. and Ataga A. E. 2012. Fungi associated with Hibiscus sabdariffa Linn (Yakwa) seed from plateau state. Scientia Africana, 11(1): 125-129.

Panna, R., Aminuzzaman, F. M., Islam, M. R. and Bhuyan, M. H. M. B. 2009: Evaluation of some physical seed treatments against Bipolaris sorokiniana associated with wheat seeds. Int. J. Sustain. Crop Prod., 4(6): 40-41.

Singh, R. K., Dubey, S. R. and Srivastava, R. K. 2013. Studies on seed mycoflora and seed treatment with bio-agents in Mesta. Ann. Pl. Protec. Sci., 21(1): 125-127.

Tsai, P. J. and Ou, A. S. M. 2002. Colour degradation of dried Roselle during storage. Food Sci., 23, 629-640.

Wahid, A., Javed, M. S. and Idress, M. 1995. Chemical control of Fusarium root-rot, wilt and cotton rot of soybean (Glycine max L.). Pak. J. Phytopathol., 7(1): 21-24.

White, G. A., Adamson, W. C., Whiteley, E. L. and Massey, J. H. 1971. Emergence of kenaf seedlings as affected by seed fungicides. Agron. J., 63: 484-486. 